\title{
Investigation of Sorbents for Phosphorus Removal
}

\author{
Julita Šarko (iD*, Aušra Mažeikienė (iD \\ Department of Environmental Protection and Water Engineering, Faculty of Environmental Engineering, \\ Vilnius Gediminas Technical University, Vilnius, Lithuania
}

Received 06 February 2020; accepted 24 March 2020

\begin{abstract}
Nowadays, the problem of water pollution with phosphorus compounds is especially important. Wastewater treatment plants do not always meet the strict requirements for the residual total phosphorus concentration $-1 \mathrm{mg} / \mathrm{l}$ in the treated wastewater. Usually individual wastewater treatment plants have a poorer removal of phosphorus from the wastewater because they are more sensitive to fluctuations in wastewater flow and environmental conditions. Research results in the scientific literature shows that only $30-50 \%$ of the phosphorus is removed from the wastewater by conventional methods. Additional wastewater treatment is recommended for higher phosphorus removal efficiency achievement. One of the ways to remove phosphorus from wastewater is filtration through sorbents filter media. The efficiency of three sorbents - Filtralite P, foam-glass and crushed shells to remove phosphorus from biologically treated wastewater is investigated in this article. A phosphate phosphorus concentration was reduced by filtering wastewater through sorbents filter media during the experiment. Concentrations of treated wastewater pollutants, filtration rate, efficiency of sorbents to remove phosphorus from the wastewater were measured and evaluated. Experiment results showed that phosphate phosphorus was effectively removed by Filtralite $\mathrm{P}$ sorbent (removal efficiency 97-98\%), less effective were foam-glass (removal efficiency 66-95\%) and crushed shells sorbents (removal efficiency 39-50\%).
\end{abstract}

Keywords: wastewater, phosphorus removal, Filtralite P, foam-glass, shells.

\section{Introduction}

Usually contaminants from domestic wastewater are removed by biological wastewater treatment plants and treated water can be released to the nature water bodies. Wastewater treatment efficiency and residual contaminants concentrations in the treated wastewater shows the quality of wastewater treatment. Nowadays with conventional wastewater treatment technologies, the highest contaminant removal efficiency (99\%) is achieved only by biochemical oxygen demand (BOD) indicator, while other indicators: chemical oxygen demand (COD), total suspended solids (TSS), total phosphorus (TP) and total nitrogen (TN) shows lower efficiencies. Phosphorus compounds get into natural water bodies with untreated or insufficiently treated wastewater. Discharges of phosphates from wastewater treatment systems generally contribute to eutrophication problems. Excess of phosphorus dissolved in water as a nutrient leads to rapid growth of algae (Ramasahayam et al., 2014). Large amounts of phosphorus can have detrimental effect on the $\mathrm{pH}$ and oxygen concentrations that can disturb the ecological balance (Powley et al., 2016). According to Regulation on Wastewater Management of the Republic of Lithuania in large wastewater treatment plants (which population equivalent (PE) is more than 100000), the concentration of total phosphorus (TP) in the treated wastewater must be less than $1 \mathrm{mg} / \mathrm{l}$. Smaller wastewater treatment plants usually works less effective than large: their contaminants removal efficiency from wastewater is lower and residual contaminants concentrations in effluent is higher. The requirements for wastewater treatment are constantly increasing in the world, in view of wastewater discharge and the characteristics of the treated wastewater receiver (river, canal). The lower maximum allowable concentration and the higher the minimal treatment efficiency (in percentage) must be achieved, when there is the more sensitive the treated wastewater receiver and the larger agglomeration (Ministry of Environment of the Republic of Lithuania, 2006). Recently, it is admitted that even the smallest wastewater treatment plants (with a flow rate of up to $5 \mathrm{~m}^{3}$ per day) can pollute the environment with insufficiently treated wastewater (Gill et al., 2009; Massoud et al., 2009; Matulova et al., 2010; Mažeikiené \& Vaiškūnaitè, 2018; Oakley et al., 2010; Powley et al., 2016). Research results in the scientific literature shows that only $30-50 \%$ of the phosphorus is removed from the wastewater by conventional methods (Ramasahayam et al., 2014; Vidal et al., 2018). Two methods are commonly used for phosphorus removal: chemical precipitation and biological purification. During this processes, phosphates are only transferred from the liquid to the solid (sludge) phase, which later must be placed somewhere. These two methods mentioned above are sensitive to seasonal and

${ }^{*}$ Corresponding author. E-mail: julita.starenko@gmail.com

\section{Copyright (C) 2020 The Author(s). Published by VGTU Press}

This is an Open Access article distributed under the terms of the Creative Commons Attribution License (http://creativecommons.org/licenses/by/4.0/), which permits unrestricted use, distribution, and reproduction in any medium, provided the original author and source are credited. 
daily temperature variations and changes in wastewater composition. Furthermore, complete removal of phosphorus is impossible due to thermodynamic and kinetic limitations. The Regulation on Wastewater Management of the Republic of Lithuania requires that concentration of phosphorus compounds in treated wastewater by small biological wastewater treatment plants (with a flow rate of up to $5 \mathrm{~m}^{3}$ per day) must be lower than $5 \mathrm{mg} / \mathrm{l}$. In some northern countries of the European Union (Finland, Sweden) these requirements are even stricter, for example the total phosphorus concentration in treated wastewater must not exceed $1 \mathrm{mg} / \mathrm{l}$. It is not always possible to achieve this level of wastewater treatment using the conventional stages of wastewater treatment nowadays. When the required treatment efficiency is not achieved during the main wastewater treatment the additional wastewater treatment is used. Additional wastewater treatment should be applied to all agglomerations of more than 10000 PE due to the guideline from European Union (EU Directive 91/271/EEC) (European Commission, 1991). According to this directive, the whole territory of Lithuania is classified as a zone sensitive to eutrophication; therefore it is especially important to remove nitrogen and phosphorus compounds from wastewater. Phosphorus concentration in water bodies is much higher than allowable due to inefficient wastewater treatment (Ramasahayam et al., 2014). Additional wastewater treatment is needed to solve the problem (Chowdhury et al., 2017; Garcia-Ivars et al., 2017; Tran et al., 2012). Additional wastewater treatment has not been studied widely until now, because due to the increasing requirements for treated wastewater, these studies are constantly gaining popularity. Wastewater can be treated additionally by filtration through filter media or membranes, adsorption, ion exchange, coagulation-flocculation and these methods combinations. Recently a lot of attention has been given to electrochemical technologies. However there are some disadvantages of additional wastewater treatment plants: they usually take up a lot of space, require skilled maintenance and filter washing process is complicated (Biswas \& Mishra, 2016; Garcia-Ivars et al., 2017; Serra et al., 2014). Filtration of treated wastewater is an appropriate method of additional treatment, because the filters are reliable and have the potential to withstand water quality fluctuations. Also filters can be constructed using local building materials and do not require electrical pumps if the filters are designed for gravitational wastewater flow. Filtration trough activated carbon is effective method in removing pesticides and drinking water preparation, but it is inappropriate for domestic wastewater treatment, because the filtration system tends to get stuffed due to suspended solids (Hedström, 2006). Extremely high wastewater treatment efficiency (99\%) is achieved with filtration through membrane, however it is one of the most complicated and expensive wastewater treatment method. Filters filled with sorbents as a filter media could be suitable for additional wastewater treatment. In this point of view, sorbents must not only reduce pollutant concentration in treated wastewater, but also be environmentally friendly and do not contaminate treated wastewater with toxic substances. So, there is a need for research of suitable sorbents for such an additional wastewater treatment method. Effectiveness of three sorbents: Filtralite P, foam-glass and crushed shells to remove phosphorus from biologically treated wastewater was researched in this article.

\section{Materials and methods}

Biologically treated wastewater for this research was taken three times from small (with a flow rate of up to $5 \mathrm{~m}^{3}$ per day) individual wastewater treatment plants (WWTPs) located in Vilnius city garden communities. Samples of 35 liters of treated wastewater were taken from the WWTPs at the same time of the day (approximately 7:30 am) and their temperature was measured at that moment. The samples of wastewater were transported for analysis to the laboratory of the Department of Environmental Protection and Water Engineering at Vilnius Gediminas technical University (VGTU) and warmed up to room temperature $\left(20^{\circ} \mathrm{C}\right)$ for measuring their $\mathrm{pH}$, biochemical oxygen demand (BOD) and the concentrations of total suspended solids (TSS), nitrate nitrogen $\left(\mathrm{NO}_{3}-\mathrm{N}\right)$ and orthophosphate phosphorus $\left(\mathrm{PO}_{4}-\mathrm{P}\right)$. Each sample was tested in triplicate providing the mean values of the results obtained. Biologically treated wastewater was uniformly distributed through filtration columns. Filtration rates $-0.5 ; 1.0$; $1.5 \mathrm{~m} / \mathrm{h}$ were selected. During the experiments, filtrate samples were taken from all columns at the same time $(0.5-$ $1.0 \mathrm{~h}$ intervals). Phosphate phosphorus concentrations were measured in the filtrate samples. The phosphate phosphorus removal efficiency from wastewater was calculated according to formula (1):

$$
E=\frac{C_{1}-C_{2}}{C_{1}} \cdot 100(\%),
$$

where: $E$ - effectiveness of removing phosphate phosphorus, $\%$; $C_{1}-\mathrm{PO}_{4}-\mathrm{P}$ concentration before filtration, $\mathrm{mg} / \mathrm{l}$; $C_{2}-\mathrm{PO}_{4}-\mathrm{P}$ concentration after filtration, $\mathrm{mg} / \mathrm{l}$.

\subsection{Methods of analysis}

The values of wastewater quality indicators were determined by applying standard analytical methods The temperature of wastewater was measured with SevenGo pro SG6 meter (Mettler Toledo, Switzerland). $\mathrm{pH}$ was determined using a WTW production pH-meter pH-330i (LST EN ISO 10523:2012), as the quality control of the measurements using Hamilton (Switzerland) certified reference buffers $\mathrm{pH} 7.00 \pm 0.01$ and $\mathrm{pH} 9.21 \pm 0.02$. The biochemical oxygen demand (BOD) in wastewater was determined by an electrometric method, for measurements 
using WTW production oxygen meter ino Lab OXI-730 according to a methodology approved by LAND 47-1:2007. The concentration of suspended solids was evaluated by gravimetric method, filtering wastewater through glass fiber filter (LAND 46-2007), weighed by KERN (Germany) ABJ 220-4M electronic laboratory scale. The suspended solids concentration was calculated according to formula (2):

$$
C=\frac{1000 \cdot\left(m_{2}-m_{1}\right)}{V_{b}}(\mathrm{mg} / \mathrm{l}),
$$

where: $C$ - the concentration of total suspended solids, $\mathrm{mg} / \mathrm{l} ; m_{2}-$ the mass of the filter after filtration, $\mathrm{mg} ; m_{1}-$ the mass of the filter before filtration, $\mathrm{mg} ; V_{b}$ - filtered volume of the sample, $\mathrm{ml}$.

Nitrate nitrogen was tested using the Spectroquant test. Concentrations were adjusted with sulfosalicylic acid (LST ISO 7890-3:1998). Phosphorus ( $\mathrm{PO}_{4}-\mathrm{P}$ ) phosphorus was determined using ammonium molybdate (LAND 58: 2003). Absorption measurements were made by pouring test samples into cuvettes (Hellma) and measuring at the required wavelength with a Genesys $10 \mathrm{UV}$-Vis spectrophotometer (Thermo Fisher Scientific, USA).

\subsection{Experimental stand and sorbents}

Experimental filter column stand was installed in the laboratory at the Department of Environmental Protection and Water Engineering of VGTU (Figure 1).

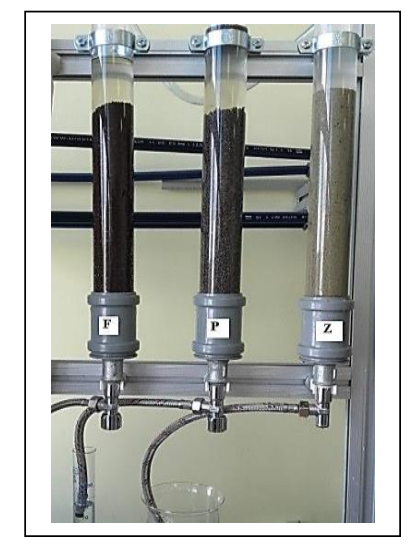

Figure 1. The stand for filtration columns filled with:

F - Filtralite P (I), P - foam-glass (II) and Z - crushed shells (III)

The stand consisted of three columns of equal diameter $(4.5 \mathrm{~cm})$. The each filter has a cross-section area of $15.9 \mathrm{~cm}^{2}$, i.e. $0.00159 \mathrm{~m}^{2}$. Each column was filled with one of three sorbents - Filtralite P, foam-glass and crushed shells. Every filter media had the same volume -0.5 liters. The sorbents were placed on a supporting layer - small stones. The wastewater was poured into the columns in the way that the sorbents were always submerged and filtration was carried out from top to bottom. About 10 liters of wastewater were filtered through a single column for each experiment. The filtration rate was controlled by adjusting the valves at the bottom of the columns and the volume was determined applying the volumetric method. During the experiments, filtrate samples were taken from all columns at the same time.

The first experimental stand column was filled with Filtralite P filter media (Maxit As, Norway). Filtralite P is specially designed high-quality filter media, manufactured from expanded clay material and with its high content of limestone, improves phosphorus removal from waste and effluent waters. Filtralite P consists of clay granules with large specific surface area and high porosity. This filter media can be characterized by high $\mathrm{pH}$ and the high levels of calcium and magnesium oxides $(\mathrm{CaO}$ and $\mathrm{MgO})$. The particles of the investigated Filtralite $\mathrm{P}$ filter media had a size of $0.5-4 \mathrm{~mm}$, bulk density of $370 \mathrm{~kg} / \mathrm{m}^{3}$, an actual particle density of $910 \mathrm{~kg} / \mathrm{m}^{3}$, a particle porosity of $\sim 65 \%$, a porosity of filter media of $\sim 60 \%$, a $\mathrm{pH}$ of filter media -12 , alkalinity -35 meq/l (Filtralite, 2018). Filtralite $\mathrm{P}$ granules usually have a size of 0.5 to $4 \mathrm{~mm}$. In this study, Filtralite P was sieved through a sieve (ISO3310-1: 2000) with a fraction of $2.5-3.15 \mathrm{~mm}$.

The second experimental stand column was filled with foam-glass filter media. The research used foam-glass granules produced by UAB "Stikloporas" (Druskininkai, Lithuania) production line. The volume of this filter media was 0.51 and the weight was $0.185 \mathrm{~kg}$. There is findings in the scientific literature that foam-glass granules can be used in water treatment technologies (Žurauskienè et al., 2017). The foam-glass is made from secondary raw materials, do not leaving third-order raw materials. Granulated foam-glass - it is an inorganic thermo-insulated material, produced from broken glass, in the form of small porous granules. Foam-glass is a unique organic material that has a porous internal structure. The sorption properties of the foam-glass depend on the size of the granules. For 
this study, the size of the particles had to be similar in order to compare the different materials, so during the experiment, the foam-glass was sieved through a sieve (ISO 3310-1:2000) with a fraction of 2.5-3.15 mm.

The third experimental stand column was filled with crushed shells filter media. Shells of marine bivalve mollusks were collected by scraping them from metal structures that are underwater. Shells are an eco-friendly material and a sort of waste that could be used as sorbent of phosphorus because it contains calcium. The volume of this filter media was 0.51 and the weight was $0.377 \mathrm{~kg}$. For this research, the size of the particles had to be similar in order to compare the different materials, so during the experiment, the crushed shells were sieved through a sieve (ISO3310-1: 2000), with a fraction of 2.5-3.15 mm.

\section{Results and discussion}

The contaminants values of biologically treated domestic wastewater are presented in Table 1 .

Table 1. Concentrations of contaminants in biologically treated wastewater $(\mathrm{mg} / \mathrm{l})$ and $\mathrm{pH}$

\begin{tabular}{|c|c|c|c|c|c|}
\hline Sample No. & TSS & $\mathrm{pH}$ & $\mathrm{BOD} 7$ & $\mathrm{NO}_{3}-\mathrm{N}$ & $\mathrm{PO}_{4}-\mathrm{P}$ \\
\hline I & $12 \pm 2$ & $7.4 \pm 0.2$ & $15.0 \pm 4$ & $0.56 \pm 0.3$ & $8.5 \pm 2$ \\
\hline II & $8 \pm 1$ & $8.5 \pm 0.2$ & $9.5 \pm 3$ & $22.9 \pm 2$ & $11.0 \pm 2$ \\
\hline III & $16 \pm 2$ & $7.9 \pm 0.2$ & $11.6 \pm 4$ & $25.0 \pm 3$ & $12.5 \pm 2$ \\
\hline
\end{tabular}

The data presented in Table 1 show that the $\mathrm{pH}$ of the treated wastewater is close to neutral and corresponds to the value of required for the effluent discharged into nature (in the range 6.5-8.5) (Ministry of Environment of the Republic of Lithuania, 2006). The wastewater contamination by the $\mathrm{BOD}_{7}$ parameter also meets the requirements, i.e. it is lower than maximum allowable concentration of $40 \mathrm{mg} / \mathrm{l}$. The concentration of nitrate nitrogen in sample No. 3 is too large for treated wastewater to be released into the natural environment. The Republic of Lithuania Wastewater Management Regulation requires that small biological treatment plants with a daily flow not exceeding $5 \mathrm{~m}^{3}$ have maximum concentration for nitrogen compounds lower than $25 \mathrm{mg} / \mathrm{l}$. In this case, only nitrate nitrogen, which is only a part of the total nitrogen, concentration is up to $25,0 \pm 3 \mathrm{mg} / \mathrm{l}$. Phosphate phosphorus concentration is more than $5 \mathrm{mg} / \mathrm{l}$ in all samples, therefore treated wastewater cannot be discharged into the environment and requires additional treatment.

Filtration in all columns lasted 12.5 hours by filtration rate $0.5 \mathrm{~m} / \mathrm{h}$ and the wastewater in the filter media was for 0.63 hour. Results from the filtration through three columns of 101 wastewater for each column at filtration rate $0.5 \mathrm{~m} / \mathrm{h}$ are presented in Figure 2.

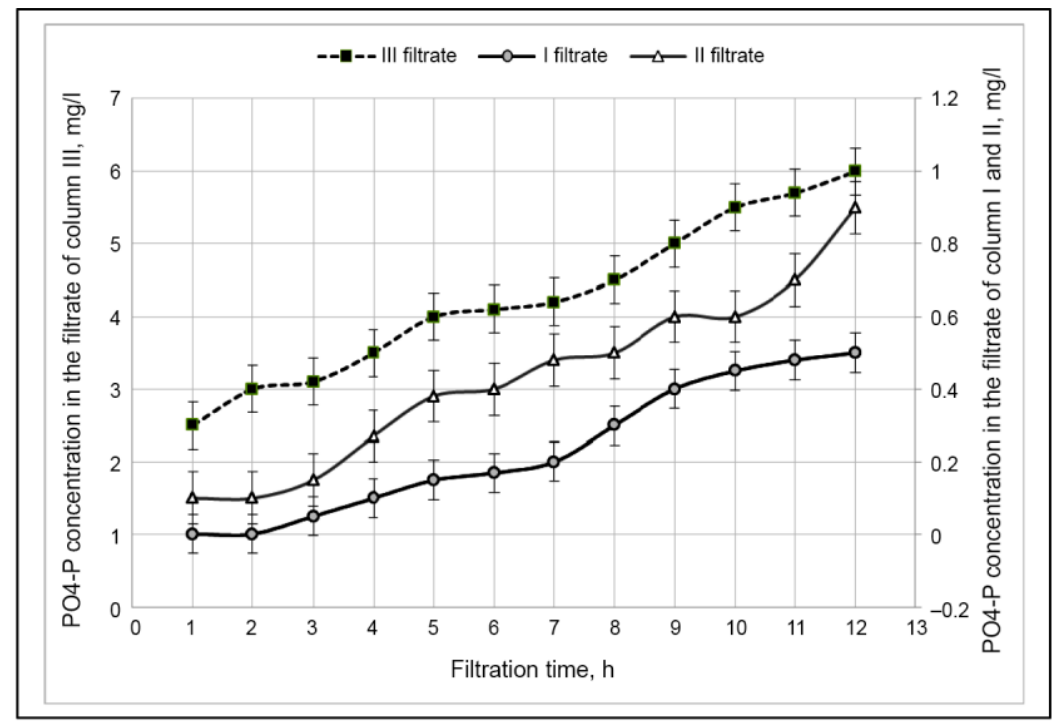

Figure 2. Results obtained by filtration of wastewater at a filtration rate $0.5 \mathrm{~m} / \mathrm{h}$.

Here: I - filtrate from the column with Filtralite P, II - filtrate from the column with foam-glass, III - filtrate from the column with crushed shells

The results presented in Figure 2 show that after 12 hours of filtration, the filtrate retained less than $1 \mathrm{mg} / \mathrm{lof}$ phosphate phosphorus after the filtration through Filtralite $\mathrm{P}$ and the foam-glass filter media, whereas the $\mathrm{PO}_{4}-\mathrm{P}$ concentration in the filtrate increased to $6 \mathrm{mg} / \mathrm{l}$ after filtration through the crushed shells filter media. According to 
the authors (Ádám et al., 2007; Filtralite, 2018; Tran et al., 2012) Filtralite P contains calcium. Calcium is also found in shells and foam-glass (Žurauskiene et al., 2017). Calcium mediates the chemical adsorption of $\mathrm{PO}_{4}-\mathrm{P}$ according to the equation:

$$
5 \mathrm{Ca}^{2+}+7 \mathrm{OH}^{-}+3 \mathrm{H}_{2} \mathrm{PO}_{4}^{-} \rightarrow \mathrm{Ca}_{5} \mathrm{OH}\left(\mathrm{PO}_{4}\right)_{3}+6 \mathrm{H}_{2} \mathrm{O}
$$

This adsorption is good in water, but the removal of $\mathrm{PO}_{4}-\mathrm{P}$ from wastewater makes the removal of phosphorus by calcite complicated because of the organic compounds in the wastewater.

Filtration in all columns lasted 6.25 hours by filtration rate $1.0 \mathrm{~m} / \mathrm{h}$ and the wastewater in the filter media was for 0.31 hour. Results from the filtration through three columns of 101 wastewater for each column at filtration rate $1.0 \mathrm{~m} / \mathrm{h}$ are presented in Figure 3.

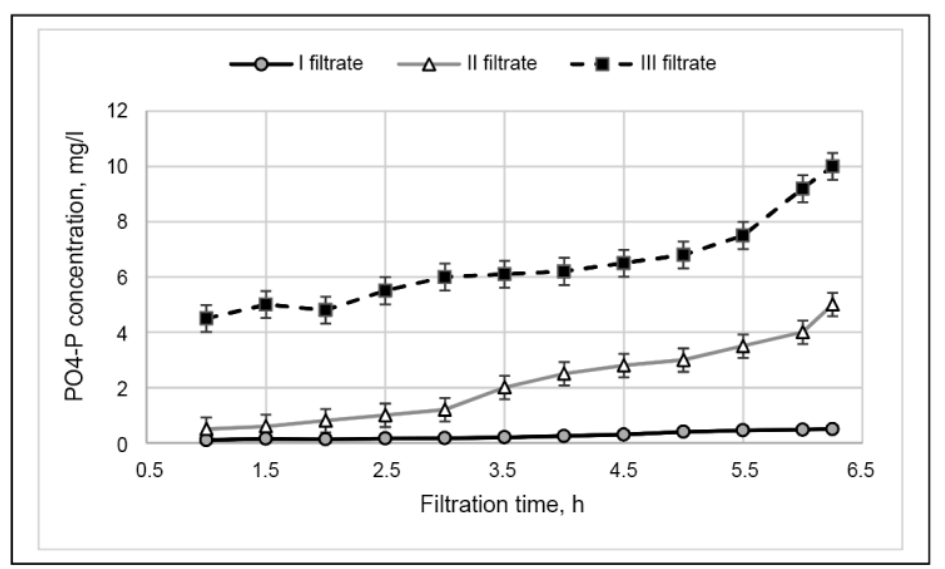

Figure 3. Results obtained by filtration of wastewater at a filtration rate $1.0 \mathrm{~m} / \mathrm{h}$. Here: I - filtrate from the column with Filtralite P, II - filtrate from the column with foam-glass, III - filtrate from the column with crushed shells

The results presented in Figure 3 show that after 6.25 hours of filtration less than $6.2 \mathrm{mg} / \mathrm{l}$ of phosphate phosphorus remained in the filtrate after filtration through Filtralite $\mathrm{P}$ filter media. Phosphate phosphorus concentration was less than $5 \mathrm{mg} / \mathrm{l}$ during filtration of wastewater through a foam-glass filter media for $6 \mathrm{~h}$, but after $15 \mathrm{~min}$ this value was already exceeded. The $5 \mathrm{mg} / \mathrm{l}$ phosphate phosphorus concentration in the filtrate was reached after 1.5 hours of filtration through crushed shells filter media.

Filtration in all columns lasted 4.2 hours by filtration rate $1.5 \mathrm{~m} / \mathrm{h}$ and the wastewater in the filter media was for 0.21 hour. Results from the filtration through three columns of 101 wastewater for each column at filtration rate $1.5 \mathrm{~m} / \mathrm{h}$ are presented in Figure 4.

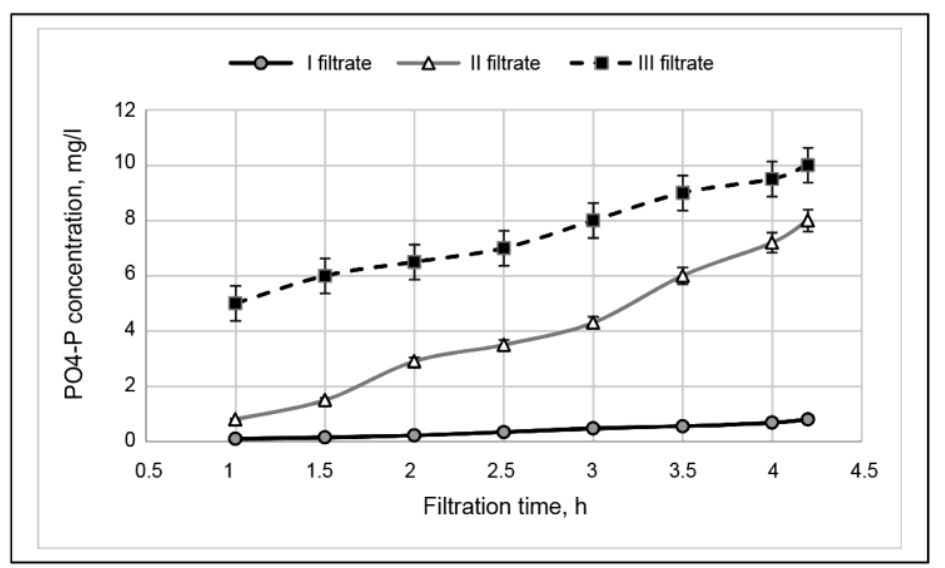

Figure 4. Results obtained by filtration of wastewater at a filtration rate $1.5 \mathrm{~m} / \mathrm{h}$. Here: I - filtrate from the column with Filtralite P, II - filtrate from the column with foam-glass, III - filtrate from the column with crushed shells

The results presented in Figure 4 show that after 4.2 hours of filtration less than $1 \mathrm{mg} / \mathrm{l}$ of phosphate phosphorus remained in the filtrate after filtration through Filtralite $\mathrm{P}$ filter media. Phosphate phosphorus concentration was less than $5 \mathrm{mg} / \mathrm{l}$ during filtration of wastewater through a foam-glass filter media for $3 \mathrm{~h}$, but after 30 min this value 
increased to $6 \mathrm{mg} / \mathrm{l}$. The $5 \mathrm{mg} / \mathrm{l}$ phosphate phosphorus concentration in the filtrate was reached after 0.5 hours of filtration through crushed shells filter media.

The average efficiency of phosphate phosphorus removal from wastewater is presented in Figure 5.

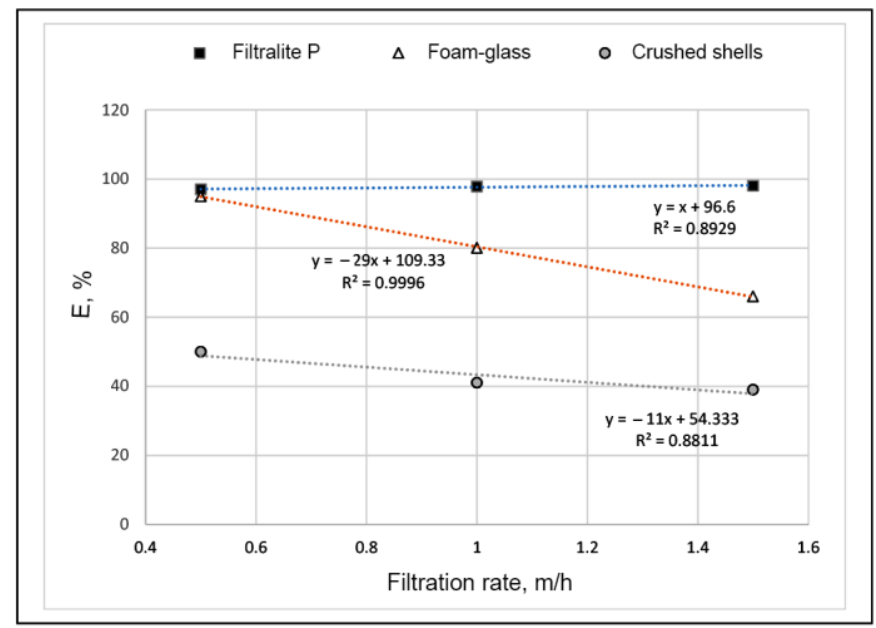

Figure 5. Phosphorus removal efficiency of wastewater filtration at rates $0.5,1.0$ and $1.5 \mathrm{~m} / \mathrm{h}$

The results presented in Figure 5 show that the efficiency of phosphate phosphorus removal from the wastewater depends on the filtration rate: when the filtration rate increases and the wastewater presence time in the filter media decreases, the efficiency of phosphate phosphorus removal from the wastewater decreases. Using Filtralite $\mathrm{P}$ filter media and increasing filtration rate from $0.5 \mathrm{~m} / \mathrm{h}$ to $1.5 \mathrm{~m} / \mathrm{h}$ reduced $\mathrm{PO}_{4}-\mathrm{P}_{\text {removal efficiency from }}$ 98 to $97 \%$. The use foam-glass filter media and crushed shells filter media resulted in a reduction of $\mathrm{PO}_{4}-\mathrm{P}$ removal efficiency from 95 to $66 \%$ and from 50 to $39 \%$, respectively. The $\mathrm{PO}_{4}-\mathrm{P}$ removal efficiency was also influenced by the initial concentration in the treated wastewater (Table 1). In sample No. 3, the initial concentration of $\mathrm{PO}_{4}-\mathrm{P}$ was $12.5 \pm 2 \mathrm{mg} / \mathrm{l}$, i.e. $32 \%$ higher than in sample No. 1. By filtering real wastewater, $\mathrm{PO}_{4}-\mathrm{P}$ removal efficiency was reduced by other pollutants in the wastewater. The authors (Berg et al., 2005) note that reducing phosphorus by filtration through calcite and crushed concrete was more effective when using artificial solutions. It should be noted that by removing phosphorus from artificial solutions, its concentration in water has been reduced from 10 to $2 \mathrm{mg} 1$ (Petrušienè, 2009). During this experiment the corresponding result was achieved only with the Filtralite $\mathrm{P}$ filter media. Crushed shells, although contains calcium, were not very effective; the average removal efficiency of $\mathrm{PO}_{4}-\mathrm{P}$ by filtration at a rate $0.5 \mathrm{~m} / \mathrm{h}$ was $50 \%$. According to scientific literature, most wastewater is saturated with calcium and phosphate compounds, but chemical precipitation is rare and requires crystallizers. Sand can be used as a crystallizer to induce the crystallization process (Gustafsson et al., 2008; Petrušienè, 2009). In this experiment no sand was used. A foam-glass filter media turned out to be more effective sorbent than crushed shells. During this experiment, phosphate phosphorus concentrations after filtration through a foam-glass filter media at a rate of $0.5 \mathrm{~m} / \mathrm{h}$ were below the requirements $(5 \mathrm{mg} / \mathrm{l})$. However, this experiment was relatively short (6 and 12 hours), with 101 of wastewater being filtered through the fillers, so the sorption capacity of the filter media was not fully exhausted. This experiment allowed the comparison of three sorbents as a filter media for treated wastewater filtration. Filtralite $\mathrm{P}$ sorbent, which was most effective in removing $\mathrm{PO}_{4}-\mathrm{P}$ from wastewater, is an expensive product (Filtralite, 2018). It could be replaced by cheaper sorbents - foam-glass or shells. It is recommended investigate the use of these materials for the sorption of $\mathrm{PO}_{4}-\mathrm{P}$ from wastewater further with reducing the filtration rate and increasing the wastewater presence time in filter media.

\section{Conclusions}

1. The average efficiency of the investigated sorbents for the removal of phosphate phosphorus from biologically treated wastewater was: Filtralite $\mathrm{P}-98 \%$, foam-glass $-81 \%$, crushed shells $-45 \%$.

2. Under the conditions of this experiment, at a filtration rate $0.5 \mathrm{~m} / \mathrm{h}$, only Filtralite $\mathrm{P}$ and foam-glass sorbents were capable to remove phosphate phosphorus from the wastewater, leaving the residual concentration PO4$\mathrm{P}$ less than $1 \mathrm{mg} / \mathrm{l}$. In the same conditions, PO4-P concentration from 2.5 to $6.0 \mathrm{mg} / \mathrm{l}$ remained in the wastewater after filtration trough crushed shells sorbent.

3. During filtration through Filtralite P, foam-glass and crushed shells sorbents, the efficiency of phosphorus removal of phosphorus from the wastewater decreased with increasing filtration rate (from 0.5 to $1.5 \mathrm{~m} / \mathrm{h}$ ) and decreasing the duration of wastewater presence in filter media (from 0.63 to $0.21 \mathrm{~h}$ ). 
4. Foam-glass or shells are wastes that could be used to remove phosphorus compounds from wastewater. It is recommended to investigate the potential of these materials further for the sorption of $\mathrm{PO}_{4}-\mathrm{P}$ from wastewater.

\section{References}

Ádám, K., Krogstad, T., Vråle, L., Søvik, A. K., \& Jenssen, P. D. (2007). Phosphorus retention in the filter materials shellsand and Filtralite $\mathrm{P} \circledast$-Batch and column experiment with synthetic $\mathrm{P}$ solution and secondary wastewater. Ecological Engineering, 29(2), 200-208. https://doi.org/10.1016/j.ecoleng.2006.09.021

Berg, U., Donnert, D., Ehbrecht, A., Bumiller, W., Kusche, I., Weidler, P. G., \& Nüesch, R. (2005). "Active filtration” for the elimination and recovery of phosphorus from waste water. Colloids and Surfaces A: Physicochemical and Engineering Aspects, 265(1-3), 141-148. https://doi.org/10.1016/j.colsurfa.2004.10.135

Biswas, S., \& Mishra, U. (2016). Treatment of Copper contaminated municipal wastewater by using UASB reactor and sandchemically carbonized rubber wood sawdust column. BioMed Research International, 2016, 5762781. https://doi.org/10.1155/2016/5762781

Chowdhury, R. B., Moore, G. A., Weatherley, A. J., \& Arora, M. (2017, January 1). Key sustainability challenges for the global phosphorus resource, their implications for global food security, and options for mitigation. Journal of Cleaner Production, 140, 945-963. https://doi.org/10.1016/j.jclepro.2016.07.012

European Commission. (1991). Council directive 91/271/EEC of 21 May 1991 concerning urban waste-water treatment, Off. J. Eur. Union L135, 40-52. https://eur-lex.europa.eu/legal-content/EN/TXT/?uri=CELEX:31991L0271

Filtralite. (2018). Product specification of filtralite nature P0-4 filter media. https://filtralite.com/en/products/filtraliter-nature-p-0-4

Garcia-Ivars, J., Martella, L., Massella, M., Carbonell-Alcaina, C., Alcaina-Miranda, M. I., \& Iborra-Clar, M. I. (2017). Nanofiltration as tertiary treatment method for removing trace pharmaceutically active compounds in wastewater from wastewater treatment plants. Water Research, 125, 360-373. https://doi.org/10.1016/j.watres.2017.08.070

Gill, L. W., O’Luanaigh, N., Johnston, P. M., Misstear, B. D. R., \& O'Suilleabhain, C. (2009). Nutrient loading on subsoils from on-site wastewater effluent, comparing septic tank and secondary treatment systems. Water Research, 43(10), $2739-2749$. https://doi.org/10.1016/j.watres.2009.03.024

Gustafsson, J. P., Renman, A., Renman, G., \& Poll, K. (2008). Phosphate removal by mineral-based sorbents used in filters for small-scale wastewater treatment. Water Research, 42(1-2), 189-197. https://doi.org/10.1016/j.watres.2007.06.058

Hedström, A. (2006). Reactive filter systems for small scale wastewater treatment: A literature review. Vatten. 62(3).

International Organization for Standartization. (2000). Test sieves. Technical requirements and testing (ISO 3310-1:2000).

Lithuanian Standards Board. (1998). Water quality. Determination of nitrate. Spectrometric method using sulfosalicylic acid (LST ISO 7890-3:1998).

Lithuanian Standards Board. (2012). Water quality. Determination of pH (LST EN ISO 10523:2012).

Massoud, M. A., Tarhini, A., \& Nasr, J. A. (2009). Decentralized approaches to wastewater treatment and management: Applicability in developing countries. Journal of Environmental Management, 90(1), 652-659. https://doi.org/10.1016/j.jenvman.2008.07.001

Matulova, Z., Hlavinek, P., \& Drtil, M. (2010). One-year operation of single household membrane bioreactor plant. Water Science and Technology, 61(1), 217-226. https://doi.org/10.2166/wst.2010.785

Mažeikienè, A., \& Vaiškūnaitè, R. (2018). Analysis and assessment of biological treatment processes in a small-scale wastewater treatment plant. Polish Journal of Environmental Studies, 27(4), 1629-1638. https://doi.org/10.15244/pjoes/77955

Ministry of Environment of the Republic of Lithuania. (2003). Water quality. Determination of phosphorus. Spectrometric method using ammonium molybdate (LAND 58: 2003).

Ministry of Environment of the Republic of Lithuania. (2006). Regulation on wastewater management of the Republic of Lithuania D1-DD236. Vilnius. https://e-seimas.lrs.lt/portal/legalAct/lt/TAD/TAIS.276576/fLIuRYOYHR?jfwid=1585yy874h

Ministry of Environment of the Republic of Lithuania. (2007). Water quality. Determination of suspended solids. Method of filtering through a glass-fiber filters (LAND 46-2007).

Oakley, S. M., Gold, A. J., \& Oczkowski, A. J. (2010). Nitrogen control through decentralized wastewater treatment: Process performance and alternative management strategies. Ecological Engineering, 36(11), 1520-1531. https://doi.org/10.1016/j.ecoleng.2010.04.030

Petrušienè, K. (2009) Removal of total nitrogen and total phosphorus from biologically treated wastewater with ion exchange (Master Thesis). Vilnius Pedagogical University, Lithuania.

Powley, H. R., Dürr, H. H., Lima, A. T., Krom, M. D., \& Van Cappellen, P. (2016). Direct discharges of domestic wastewater are a major source of phosphorus and nitrogen to the Mediterranean Sea. Environmental Science and Technology, 50(16), 8722-8730. https://doi.org/10.1021/acs.est.6b01742

Ramasahayam, S. K., Guzman, L., Gunawan, G., \& Viswanathan, T. (2014). A comprehensive review of phosphorus removal technologies and processes. Journal of Macromolecular Science, Part A, 51(6), 538-545. https://doi.org/10.1080/10601325.2014.906271

Serra, T., Colomer, J., Pau, C., Mariń, M., \& Sala, L. (2014). Tertiary treatment for wastewater reuse based on the Daphnia magna filtration - Comparison with conventional tertiary treatments. Water Science and Technology, 70(4), 705-711. https://doi.org/10.2166/wst.2014.284 
Tran, N., Drogui, P., Blais, J. F., \& Mercier, G. (2012). Phosphorus removal from spiked municipal wastewater using either electrochemical coagulation or chemical coagulation as tertiary treatment. Separation and Purification Technology, 95, 1625. https://doi.org/10.1016/j.seppur.2012.04.014

Vidal, B., Hedström, A., \& Herrmann, I. (2018). Phosphorus reduction in filters for on-site wastewater treatment. Journal of Water Process Engineering, 22, 210-217. https://doi.org/10.1016/j.jwpe.2018.02.005

Žurauskienė, R., Valentukevičienė, M., \& Žurauskaitė, R. (2017). Filter Medias from Granulated Foam-glass, Properties Investigated for Water Treatment Possibilities. Mokslas - Lietuvos Ateitis, 9(4), 419-423. https://doi.org/10.3846/mla.2017.1056 